\title{
STRETCHING RICO TO THE LIMIT AND BEYOND
}

\author{
ALEXANDER M. PARKER
}

There are some instances when a law is just on its face and unjust in its application.... [B]ut when the ordinance is used ... to deny citizens the First Amendment privilege of peaceful assembly and peaceful protest, then it becomes unjust. ${ }^{1}$

\section{INTRODUCTION}

In 1970, finding that "organized crime in the United States is a highly sophisticated, diversified, and widespread activity that annually drains billions of dollars from America's economy,"2 Congress enacted the Organized Crime Control Act of 1970 (OCCA). ${ }^{3}$ Title IX of the OCCA, also known as the Racketeer Influenced and Corrupt Organizations Act (RICO), ${ }^{4}$ contains both criminal and civil provisions that are designed to eliminate the influence of organized crime on American business. Prior to 1980, RICO was applied almost exclusively to criminal prosecutions. ${ }^{5}$ Since then, however, civil RICO suits have gone beyond the underworld of organized crime and have becoine common in areas such as coinnon commercial fraud, securities fraud, and antitrust violations. ${ }^{6}$

In recent years, there has been a great deal of concern ainong commentators and practitioners that the application of civil RICO has expanded well beyond its intended sphere-and, indeed, be-

1. MARTIN LUTHER KING, JR., Letter from the Birmingham City Jail, in A TESTAMENT OF HOPE: THE ESSENTIAL WRITINGS OF MARTIN LUTHER KING, JR. 289, 294 (1986).

2. Organized Crime Control Act of 1970, Pub. L. No. 91-452, 84 Stat. 922, 922 (codified in scattered sections of 18 U.S.C.).

3. Id.

4. 18 U.S.C. $\S \S 1961-1968$ (1994).

5. REPORT OF THE AD HOC CIVIL RICO TASK FORCE OF THE A.B.A. SECTION OF CORPORATION, BANKING AND BUSINESS LAW 1, 55 (1985) (finding only nine decisions involving civil RICO before 1980).

6. Id. at 57. The report noted that of the 300 civil RICO cases surveyed, $40 \%$ involved securities fraud, $37 \%$ involved common law fraud in a commercial or business setting, and $4 \%$ concerned antitrust or unfair competition. 
yond what is constitutionally permissible-particularly when applied to individuals engaged in what this Note refers to as "protest activity." Focusing on the fact that RICO permits civil plaintiffs to recover triple their provable damages, ${ }^{8}$ these critics argue that the availability of such extraordinary damages will have an unacceptable chilling effect on constitutionally protected speecl. Despite this criticisin, the courts have regularly ruled in favor of broad interpretations of RICO. ${ }^{9}$ In decisions defining its pattern and enterprise requireinents, the Supreme Court and lower federal courts have stretclied RICO to the broadest interpretation that its statutory language can withstand. ${ }^{10}$

To fully understand the extent of this reach, however, one must look beyond RICO itself. Because of its structure, the breadtli of RICO is directly related to the breadth of its predicate offenses, for without a predicate offense no RICO liability can arise. This is because RICO hability extends only when the defendant has engaged im a pattern of "racketeering activity" that is itself defined in terins of other criminal statutes. ${ }^{11}$ These statutes are collectively referred to as the "predicate offenses." Thus, if a defendant's actions are not mcluded within the scope of a predicate offense, neither civil nor criminal hability is possible under RICO.

When RICO is used agamst protesters, plaintiffs most frequently use Hobbs Act extortion as the predicate offense. ${ }^{12}$ This affinity exists because the courts have repeatedly extended the Hobbs Act, like RICO, to cases beyond its originally intended scope. The federal courts have rejected attempts to limit the Hobbs Act through strict readings of "property" and what it ineans to attempt to "obtain" property. ${ }^{13}$ Similarly, the courts lave refused to impose either a principled definition of "fear"14 or a narrow interpretation of "interstate commerce."15 Any of these limitations of the Hobbs Act would protect those engaged in

7. In this context, protest activity refers primarily to picketing and sit-ins, but may extend to other forms of nonviolent civil disobedience.

8. 18 U.S.C. \& 1964(c) (1994).

9. See infra Sections II(B)-(C).

10. Id.

11. 18 U.S.C. § 1961(1) (1994).

12. 18 U.S.C. § 1951 (1994).

13. See infra Section I(C).

14. See infra Section I(D).

15. See infra Section I(B). 
forms of protest activity generally thought to be protected, and even necessary, as a matter of pohicy.

Thus, this application of RICO is dependent not merely on one but two statutes that have been interpreted to their maximum scope. This Note traces the extent of these expansions and warns that at soine point the tension of this "double-stretching" of RICO and of its predicates must reach its breaking point before it can reach peaceful protesters. Part I examines the judicial expansion of Hobbs Act extortion, the predicate most commonly used against protesters, through the broad reading of its three main eleunents. Turning to the similar evolution of RICO itself, Part II discusses how courts have consistently rejected attempts to limit its reach through its pattern and enterprise requirements. Fimally, Part III analyzes several cases applying RICO and Hobbs Act extortion to those engaged im pohtical protest. This Part demonstrates that both statutes nnust be read at their nnaximum scope before they reach these types of activities. This combination results $\mathrm{m}$ a statute that purishes behavior totally unrelated to its intended target.

There are many reasons for believing that the application of RICO to protestors should not be permitted. Congress intended that both RICO and the Hobbs Act address a particular class of criminal behavior-organized crime. ${ }^{16}$ It is nothing short of incredible that such statutes have been applied so far from their primary target. This Note concludes that when pushed to this absurd limit, the statutes are stretched too thin, and courts should be unwilling to permit their application to protest activities. One need only look at our history to understand the vital role that pohtical protest has played im American pohtics. From the Boston Tea Party to the woinen's suffrage movement to the civil rights moveinent, Americans have used pubhic protest as a means of effecting political change. It is not difficult to imagine what impact RICO would have had on Dr. King's Southern Christian Leadership Council. Segregatiomist forces could have used the extraordinary dainages provision to cut the financial legs out from under the inovement. When crimes have been committed, they should be punished, but there is no need for the kind of severe penalty RICO now imposes. Nonviolent, legal protest should not be subject to extraordinary pumishment.

16. See infra Sections $\mathrm{I}(\mathrm{A})$ and II(A). 


\section{The Predicate OfFenses-HobBs ACt Extortion}

RICO prohibits various actions involving racketeering activity. ${ }^{17}$ Such activity is defined as any one of a long list of state and federal criminal acts, including violation of the Hobbs Act. ${ }^{18}$ This Act makes it a federal felony to atteinpt, conspire to, or actually interfere with interstate commerce through robbery or extortion. However, neither the language of the statute nor its legislative history specify how broad a range of activity is covered by its definition of extortion. ${ }^{19}$ As a result, courts have permitted ambitious federal prosecutors to apply the Act to situations quite different froin the classic extortion sclieme (e.g., a criminal threatens to damage a shopkeeper's store if the merchant refuses to pay an amount of money for "protection"), thereby extending federal jurisdiction to crimes previously handled by state courts. ${ }^{20}$

This growth largely has resulted from broad interpretations of the statutory language. The required effect on interstate coinunerce is now inerely a de minimis one. Similarly, courts lave broadened the types of rights considered property within the meaning of the statute. Finally, the courts have also broadened the understanding of what the statute ineans by fear, of what the victim inust be afraid, and of what colmection the defendant must liave in creating that fear.

\section{A. Legislative History of the Hobbs Act}

Of all the RICO predicate offenses, the Hobbs Act is by far used most often in cases agamst peaceful protesters. Enacted in 1945, the Hobbs Act was a response to the Supreme Court's decision in United States v. Local 807, International Brotherhood of Teamsters. ${ }^{21}$ In its holding, the Suprene Court overturned the conviction of union meinbers accused of using threats of violence to obtam wages for no labor. ${ }^{22}$ Congress passed the Hobbs Act because some of its ineinbers beheved that the Local 807 decision

17. 18 U.S.C. $\S 1962$ (1994).

18. 18 U.S.C. $\S 1961(1)(B)$ (1994) (cross-referencing 18 U.S.C. § 1951).

19. See 18 U.S.C. § 1951 (1994); S. REP. No. 1516, 79th Cong., 2d Sess. 1 (1946); H.R. REP. No. 238, 79th Cong., 1st Sess. 1 (1945).

20. See Camille Kenny, Federal Criminal Jurisdiction: A Case Against Making Federal Cases, 14 Seton Hall L. Rev. 574, 586-92 (1984).

21. 315 U.S. 521 (1942).

22. Id. at 531-39. 
had "legalize[d] in certain labor disputes the use of robbery and extortion." ${ }^{23}$ The Hobbs Act did not seek to change the substantive law of its predecessor statute, the Anti-Racketeering Act of $1934,{ }^{24}$ but did reinove its organized labor exemption. ${ }^{25}$ Indeed, although it is organized somewhat differently, the language of the Hobbs Act is substantially similar to that of the Anti-Racketeering Act. ${ }^{26}$ The interpretive process is somewhat confused, however, by a debate as to whether the Hobbs Act owes more to its predecessor or to the New York Code. ${ }^{27}$ To further inuddy the waters, others have suggested that the language has a more general common law meaning. As Rep. Russell said in the House debate, "There is no use defining those terms because they are so well defined that their definition now is a matter of common knowledge." ${ }^{28}$ Courts have done hittle to resolve this question, giving New York precedent persuasive but not controlling authority. ${ }^{29}$ Torn between mdependent bodies of law, the legislative intent as to the precise scope of what behavior constitutes extortion under the Hobbs Act remains unclear.

The debate over the legislative history of the Hobbs Act would be largely poimtless if the statute had contimued to be apphed only to racketeers and organized labor because their activities would fall within almost any definition of extortion. Over the years, however, the government has attempted to bring a broad range of activities within the definition of extortion. These activities have mcluded the actions of corrupt government officials and

23. 91 CONG. REC. 11,899, 11,900 (1945) (statement of Rep. Hancock).

24. Ch. 569, 48 Stat. 979 (codified as amended at 18 U.S.C. \& 1951 (1994)).

25. See H.R. REP. No. 238, 79th Cong., 1st Sess., tit. III (1945), reprinted in 1946 U.S.C.C.A.N. 1360, 1370.

26. The Hobbs Act, for example, defines extortion as "the obtaining of property from another, with his consent, induced by wrongful use of actual or threatened force, violence, or fear, or under color of official right." 18 U.S.C. $₹$ 1951(b)(2) (1994). The Anti-Racketeering Act, on the other hand, has no explicit definition of extortion, but punishes one who "[o]btains the property of another, with his consent, induced by wrongful use of force or fear, or under color of official right." Anti-Racketeering Act, Ch. 569, § 2(b), 48 Stat. 979,980 (1934).

27. For a nore complete analysis of this debate, see Laurel G. Sandler, Note, Extortion "Under Color of Official Right": Federal Prosecution of Official Corruption Under the Hobbs Act, 5 LOY. U. CHI. L.J. 513, 514-18 (1974).

28. 91 CONG. REC. 11,914 (1945).

29. See, e.g., Evans v. United States, 504 U.S. 255 (1992); United States v. Brecht, 540 F.2d 45, 52 n.12 (2d Cir. 1976), cer. denied, 429 U.S. 1123 (1977); United States v. Nedley, 255 F.2d 350 (3d Cir. 1958). 
commercial extortion. ${ }^{30}$ A stream of judicial decisions has broadened the statute and widened each element of a Hobbs Act prosecution to the point that the facts of extreme cases rarely even resemble those in the classic paradigm. ${ }^{31}$

\section{B. Interstate Commerce}

The first eleinent of any Hobbs Act prosecution is the obstruction of interstate commerce or the movement of any article or commodity in interstate commerce. ${ }^{32}$ The definition ${ }^{33}$ ties the jurisdictional eleinent of the Hobbs Act to the full breadth of the commerce power; and as the commerce power has expanded, so too has the Hobbs Act. ${ }^{34}$ The Supreme Court's decision in Stirone v. United States supports this view: "[The Hobbs Act] speaks in broad language, manifesting a purpose to use all the constitutional power Congress has to punish interference with interstate commerce ...."35 That interference need not be severe, however. Indeed, courts have since held that there need only be a de minimis effect on interstate commerce for the Hobbs Act to apply. ${ }^{36}$

30. See, e.g., United States v. Local 560, Int'l Bhd. of Teamsters, 780 F.2d 267 , 281-82 (3d Cir. 1985), cert. denied, 476 U.S. 1140 (1986); United States v. Kenny, 462 F.2d 1205, 1229 (3d Cir.), cert. denied, 409 U.S. 914 (1972); United States v. Hyde, 448 F.2d 815, 832-34 (5th Cir. 1971), cert. denied, 404 U.S. 1058 (1972).

31. See, e.g., United States v. Wright, 804 F.2d 843 (5th Cir.) (involving a prosecutor who accepted nioney in exchange for non-prosecution of drunk drivers), cert. denied, 481 U.S. 1013 (1986); United States v. Rabbitt, 583 F.2d 1014 (8th Cir. 1978) (dealing with state legislator who was paid to "speak favorably" about a firm), cert. denied, 489 U.S. 1116 (1979).

32. 18 U.S.C. § 1951(a) (1994).

33.

The term "commerce" means commerce within the District of Columbia, or any Territory ... ; all commerce between any point in a State . . . and any point outside thereof; all commerce between points within the same State through any place outside such state; and all other commerce over which the United States has jurisdiction.

18 U.S.C. § 1951(b)(3) (1994).

34. But see United States v. Lopez, 115 S. Ct. 1624 (1995), in which the Court refused to permit this expansion for the first time in recent nuemory. For a general discussion of the expansion of the Commerce Clause, see LAURENCE H. TRIBE, AMERICAN CONSTTUUTIONAL LAW \& 5-5 (2d ed. 1988).

35. 361 U.S. 212, 215 (1960).

36. United States v. Phillips, 577 F.2d 495, 501 (9th Cir.), cert. denied, 439 U.S. 831 (1978); United States v. Gambino, 566 F.2d 414, 418 (2d Cir. 1977), cert. denied, 435 U.S. 952 (1978). 
As an evidentiary matter, some courts of appeals have held the interstate commerce requirements to have even less consequence than the term de minimis may seem to indicate. These courts, mcluding the U.S. Courts of Appeals for the First, Second, and Ninth Circuits, have found that there need not be a showing of any actual effect at all on interstate commerce-a "probable or potential" effect is sufficient. ${ }^{37}$ For example, in United States $v$. DiGregorio, the First Circuit held that although there was no evidence showing that the victim's company was involved in any actual or planned construction projects, it was enough that "the extortion could be reasonably thought to interfere with probable future interstate commerce."38

As to the quality of the relevant evidence, the court explamed in a footnote that although the witness' "choice of the past tense [in his testimony] to describe his company's municipal construction work is soinewhat ambiguous, we believe the prosecutor's use of the present tense in his question fairly supports an inference that [the victim] was describing the present business of Chick's [company]. ${ }^{39}$ The court then reasoned that although no evidence demonstrated that the protection money deinanded would have coine from the company, the jury could fairly infer that the payment would in some way deplete corporate coffers. ${ }^{40}$ Thus, under this "depletion of the resources" 41 theory, any act that depletes the resources of a company engaging in interstate commerce obstructs interstate commerce and is subject to Hobbs Act prosecution.

This kind of reasoining, however, allows courts to accept theories of obstruction that are attenuated in the extreme. One of the best examples of this problem occurred in United States v. Wright in which the Fifth Circuit held that the Hobbs Act apphed in a case imvolving a local prosecutor who attempted to extort money from law firms in exchange for not prosecuting chents for drunk driving:

37. Phillips, 577 F.2d at 501; United States v. DiGregorio, 605 F.2d 1184, 1190 (1st Cir.), cert. denied, 444 U.S. 937 (1979); United States v. Daley, 564 F.2d 645 (2d Cir. 1977).

38. DiGregorio, $605 \mathrm{~F} .2 \mathrm{~d}$ at 1191.

39. Id at n.7.

40. Id. at $\mathbf{1 1 9 2 .}$

41. Id. at 1190; United States v. Zemek, 634 F.2d 1159, 1173 n.20 (9th Cir. 1980), cert. denied, 450 U.S. 916 (1981). 
Irrespective of whether we are sympathetic with a result that puts the federal government in the business of prosecuting petty crime of purely local concern, we cannot say that the government has failed to establish every element required by the Hobbs Act, including a connection with interstate commerce ... [T] he failure to prosecute drunk driving increases the number of wrecks on interstate highways. Wrecks on the highways impede the flow of interstate commerce thereby estabhishing the required connection between the extortionate conduct and interstate commerce. ${ }^{42}$

Thus, the interstate commerce requirement of Hobbs Act extortion is extreinely broad and of little practical consequence. Almost any act of extortion can be brought within the scope of the Hobbs Act and be prosecuted as a federal crime.

\section{Property}

A more substantive element of Hobbs Act extortion is the act of obtaming property from the victim. ${ }^{43}$ Like the interstate commerce requirement, this requirement also has seen a great deal of expansiou since the Act's imitial passage. The first of these expansions was the addition of intangible property to the Act's protection.

The classic extortion scheme is the demand for money induced by the threat of violence to the victim. There is no apparent reason, however, why the demand for less tangible property should not be mcluded within the extortion laws. Indeed, in several cases, courts have held that property rights as intangible as the right to hire einployees and to solicit customer accounts are sufficient to mvoke Hobbs Act protection. ${ }^{44}$

The next step in the expansion of the defimition of property mcorporates rights that inore closely resemble civil berties than property rights. For example, the Fourth Circuit held in United States $v$. Santoni that "the property extorted was the right ... to

42. United States v. Wright, 804 F.2d 843, 844 (5th Cir.), cert. denied, 481 U.S. 1013 (1986).

43. 18 U.S.C. \& 1951(a) (1994).

44. United States v. Lewis, 797 F.2d 358, 364 (7th Cir. 1986), cert. denied, 479 U.S. 1093 (1987); United States v. Hoelker, 765 F.2d 1422, 1425 (9th Cir. 1985), cert. denied, 475 U.S. 1024 (1986); United States v. Nadaline, 471 F.2d 340, 344 (5th Cir.), cert. denied, 411 U.S. 951 (1973); United States v. Tropiano, 418 F.2d 1069, 1075-76 (2d. Cir 1969), cert. denied, 397 U.S. 1021 (1970). 
make a business decision free from outside pressure;" extortion of this right was sufficient to invoke the Hobbs Act. ${ }^{45}$ Perhaps the most extreme case of rights held to constitute property came in a Third Circuit decision that upheld the convictions of union officials based on their depriving the union's members of their "right to democratic participation" in the union. ${ }^{46}$ The court cited a 40 year-old state court decision for the proposition that "such rights are 'as real and as needful of equitable protection, surely, as money or chattels. " tion of these rights in equity should justify the federal government's protection of them with criminal sanctions, except to say that the Hobbs Act was intended to incorporate "the common understanding of the states." ${ }^{48}$

Finally, a related line of cases has broadened the "obtains property" requirement of Hobbs Act extortion by expanding the understanding of what it nieans to obtain the property. These cases have held that the key to extortion is not the defendant's gain of the property ${ }^{49}$ but the victim's loss. In United States $v$. Clemente, the Second Circuit set forth the clearest rationale for this position by ponitnig out that "whether a Hobbs Act defendant personally receives any benefit front his alleged extortion is largely irrelevant. ${ }^{.50}$ Any act, then, that is wrongfully intended to induce an individual to give up any right he may possess can meet the second element of Hobbs Act extortion.

\section{Fear}

The third and final element of Hobbs Act extortion is that the victim be induced to give up property through "wrongful use of actual or threatened force, violence, or fear." U1 Unfortunately,

45. 585 F.2d 667, 673 (4th Cir. 1978), cert. denied, 440 U.S. 910 (1979); see also Zemek, 634 F.2d at 1174 (including the right to "make business decisions . . . free from wrongful coercion" in the definition of property).

46. United States v. Local 560 of Int'l Bhd. of Teamsters, 780 F.2d 267, 282 (3d Cir. 1985), cert. denied, 476 U.S. 1140 (1986).

47. Id. at 281 (citing Dusing v. Nuzzo, 29 N.Y.S.2d 882 (Sup. Ct. Ulster County), modified on other grounds and affd, 31 N.Y.S.2d 849 (1941)).

48. Id.

49. See United States v. Green, 350 U.S. 415, 420 (1956); United States v. Provenzano, 334 F.2d 678, 686 (3d Cir.), cert. denied, 379 U.S. 947 (1964).

50. 640 F.2d 1069, 1079 (2d Cir.), cert. denied, 454 U.S. 820 (1981).

51. 18 U.S.C. $\S 1951$ (b)(2) (1994). Note that fear is not a required element when the defendant is a public official and the inducement is "under color of official right." See 
the statute provides no definition of fear, thus leaving open questions about what fear is, what the victim must be afraid of, and what role the defendant inust have in creating that fear. The most commonly used definition of fear is "a state of anxious concern, alarm, or apprehension of anticipated harm." ${ }^{.52}$ To date, however, courts have succeeded in defining fear only by identifying what it is not. For example, in a case involving the hiring of a state legislator to speak favorably about a firm, the court held that the official's subsequent deinand for $10 \%$ of any resulting contracts was not extortionate because the firm was "a willing collaborator" and the principals "all expressed anger, not fear, at hearing of Rabbitt's ten percent deinand." 53 The court seems to have been persuaded by the fact that the only thing the firm stood to lose by refusing the deinand was the benefit of its existing agreement. ${ }^{54}$

Similarly, the Second Circuit found in United States v. Capo that a job-selling scheme involved no extortion because there was "no evidence at all to suggest that it would have been reasonable for the 'victims' to believe that if they did not pay, the defendants would exploit any such power to diminish their employment opportunities." 55 Once again, the suggestion here is that the victim inust believe that failure to participate will have some harmful or preclusive effect for the fear eleinent to be inet.

As to what the victim inust fear, courts estabhished early in the history of the Hobbs Act that the victim does not have to be afraid of physical harm for extortion to exist. They accepted that

United States v. Kenny, 462 F.2d 1205, 1229 (3d Cir.), cert. denied, 409 U.S. 914 (1972). In these cases, the government can satisfy its burden by showing that the victim acquiesced to the denuands because of the defendant's position. The Kenny court held that "while private persons nuay violate the statute only by use of fear and public officials may violate the act by use of fear, persons holding public office nuay also violate the statute by a wrongful taking under color of official right." Id. at 1229. While courts largely have adopted this position, commentators remain divided. See generally Thoinas H. Henderson, The Expanding Role of Federal Prosecutors in Combating State and Local Political Corruption, 8 CUMB. L. REv. 385 (1977); James P. Fleissner, Prosecuting Officials Under the Hobbs Act: Inducement as an Element of Extortion Under Color of Official Right, 52 U. CHI. L. REV. 1066 (1985); Note, supra note 27, at 515-18 (discussing the past and present application of the Hobbs Act to corrupt public officials).

52. E.g., United States v. Brecht, 540 F.2d 45, 52 (2d Cir. 1976), cert. denied, 429 U.S. 1123 (1977); United States v. Bryson, 418 F. Supp. 818, 825 (W.D. Okla. 1975); Kenny, 462 F.2d at 1229.

53. Umited States v. Rabbitt, 583 F.2d 1014, 1027 (8th Cir. 1978), cert. denied, 439 U.S. 1116 (1979).

54. 583 F.2d at 1027 n. 25 .

55. 817 F.2d 947, 951 (2d Cir. 1987) (en banc). 
the fear of "economic loss" would meet the fear requirement. ${ }^{56}$ This view is interpreted broadly and has been held to encompass not only certain future economic loss such as the termination of contracts but prospective opportunities as well. ${ }^{57}$

Courts recently have gone one step further and found that the defendant need not even be responsible for the harm the victim fears. On the contrary, the defendant merely has to take advantage of the circumstances and the victim's fear. For example, in United States v. Duhon, the Fifth Circuit held that when the victim faced impending labor difficulties, "[t]he crucial issue is whether defendants intended to induce the $\$ 5,000$ payment by exploiting Buckholtz's fear of economic loss [caused by picketing] .... The defendant need not have originally caused the fear, nor need the cause of the fear itself be wrongful. ${ }^{\prime 58}$

At least one court has gone even one step further and found extortion when the source of the victim's fear was the general economic climate. In United States $v$. Shine, the court permitted a conviction on the basis that the victim paid the defendant to keep a construction contract because hitle other construction work was available in the area. ${ }^{59}$ Moreover, the defendant does not need to have the ability to prevent the anticipated harm; rather, the victim merely needs a reasonable behef that it is so. ${ }^{60}$

The great problein with these rulings, however, is that they render the fear requirement practically meaningless. Decoupling the defendant from the victim's fear destroys an essential characteristic of the offense. Under the broadest interpretations, it would be possible to satisfy the fear element in any case in which the victim pays money to the defendant; after all, the victim wonld not pay anytling if he were not afraid that it would somehow be worse not to.

56. See, e.g., United States v. French, 628 F.2d 1069, 1072 (8th Cir.), cert. denied, 449 U.S. 956 (1980); United States v. Duhon, 565 F.2d 345, 351 (5th Cir.), cert. denied, 435 U.S. 952 (1978); Bianchi v. United States, 219 F.2d 182, 189 (8th Cir.), cert denied, 349 U.S. 915 (1955); United States v. Dale, 223 F.2d 181, 183 (7th Cir. 1955).

57. See United States v. Hathaway, 534 F.2d 386, 395-96 (1st Cir.), cert. denied, 429 U.S. 819 (1976); United States v. Brecht, 540 F.2d 45, 52 (2d Cir. 1976), cert. denied, 429 U.S. 1123 (1977).

58. 565 F.2d 345, 351 (5th Cir.), cert. denied, 435 U.S. 952 (1978); see also French, 628 F.2d at 1072.

59. 526 F. Supp. 717, 719 (E.D.N.Y. 1981).

60. See United States v. Capo, 817 F.2d 947, 951 (2d Cir. 1987) (en banc). 
These cases demonstrate that each element of Hobbs Act extortion has gradually been interpreted to its maximum breadth. In part, this growth can be justified because there is always a final check on its application-prosecutorial discretion. Federal prosecutors are subject to significant political controls, and elected governmental officials are in a position to rem in any overzealous application of the Hobbs Act. When applied in its imcarnation as a civil RICO predicate, however, there are no pohtically answerable individuals through whom the statute will be applied, and any litigant can utilize the breadth in the statute for his own personal gain.

\section{RICO}

The breadth of $\mathrm{RICO}^{61}$ stems from the elusiveness of its im-

61. Selected provisions of the statute that apply to civil claims include the following: Definitions:

(1) "racketeering activity" means ... (B) any act which is indictable under any of the following provisions of title 18, United States Code ... section 1951 (relating to interference with commerce, robbery, or extortion).

(4) "enterprise" includes any individnal, partnership, corporation, association, or other legal entity, and any union or gronp of individuals associated in fact although not a legal entity.

18 U.S.C. § 1961 (1), (4) (1994).

Prohibited Activities:

(a) It shall be unlawful for any person who has received any income derived ... from a pattern of racketeering activity or through collection of an unlawful debt ... to use or invest ... any part of such income . . . in acquisition of any interests in, or the establishment or operation of, any enterprise which is engaged in, or the activities of whicb affect, interstate or foreign coinmerce ....

(b) It shall be unlawful for any person through a pattern of racketeering activity ... to acquire or maintain ... any interest in or control of any enterprise which is engaged in, or the activities of which affect, interstate or foreign commerce.

(c) It shall be unlawful for any person employed by or associated with any enterprise engaged in, or the activities of which affect, interstate or foreign commerce, to conduct or participate, directly or indirectly, in the conduct of such enterprise's affairs through a pattern of racketeering activity or collection of unlawful debt.

(d) It shall be unlawful for any person to conspire to violate any of the provisions of subsection (a), (b), or (c) of this section.

18 U.S.C. \& 1962(a)-(d).

Civil Remedies:

(c) Any person injured in his business or property by reason of a violation of section 1962 of this chapter may sue therefor in any appropriate United States district court and shall recover threefold the damages he sustains and the cost of the suit, including reasonable attorney's fee.

18 U.S.C. § 1964(c). 
tended target. Its legislative history reveals that Congress was concerned that an overly narrow statute would be ineffective in combating organized crime as intended. ${ }^{62}$ In the end, these concerns influenced the final version of the statute more than the concerns that the statute was overbroad. ${ }^{63}$ In retrospect, it appears that these critics had a legitimate concern. The two aspects of the statute that the supporters rehed on as limiting RICO's scope have been broadened repeatedly. On the one hand, the Supreme Court has refused to permit lower courts to interpret the statute's "pattern" requirement to require anything more than the minimum that the language of the statute clearly imphes. ${ }^{64}$ On the other hand, the Court has read the statutory "enterprise" requirement in the broadest mamer, repeatedly rejecting lower court atteinpts to reduce RICO's breadth by narrowly construing its requirements. ${ }^{65}$

\section{A. Legislative History}

Much of the debate over RICO's application stems from its potentially broad scope. After RICO was introduced into the Senate, some were concerned that it could apply not only to the Mafia and other kinds of organized criminals but also to pohitical protesters. ${ }^{66}$ In part, this overbreadth arises from Congress's decision to attack organized crime based not on what it is, but on what it does. ${ }^{67}$ RICO's supporters, however, argued that this broad interpretation was necessary if RICO was to be apphed effectively to organized crime: "It is self-defeating," argued RICO's Senate sponsor, Senator McClellan, "to attempt to exclude . . . all

62. See infra notes $66-68$ and accompanying text.

63. See infra notes 77-79 and accompanying text.

64. See infra Section II(B).

65. See infra Section $\mathrm{II}(\mathrm{C})$.

66. See Measures Relating to Organized Crime: Hearings on S. 30 and Related Measures Before the Subcomm. on Criminal Laws and Procedures of the Senate Comm. on the Judiciary, 91st Cong., 1st Sess. 475 (1969) [hereinafter Senate Hearings] (testimony of Lawrence Speiser, Director, Washington Office, ACLU); see also Adam D. Gale, Note, The Use of Civil RICO Against Antiabortion Protesters and the Economic Motive Requirement, 90 COLUM. L. REV. 1341, 1357-68 (1990).

67. This decision may have been based, at least in part, on a concern that to do otherwise would make the law unconstitutional as a criminal sanction based on status. See A.B.A. SECTION OF CORP., BANKING \& BUSINESS LAW, REPORT OF THE AD HOC CIVIL RICO TASK FORCE 90 (1985); see also Noto v. United States, 367 U.S. 290, 299-300 (1961); Lanzetta v. New Jersey, 306 U.S. 451, 458 (1939). In any case, regardless of the reason, this decision by its drafters has been the key to RICO's subsequent expansion. 
offenses which commonly are committed by persons not involved in organized crime." 68 It was clear that RICO would be ineffectual as a deterrent if it did not include offenses such as murder, drug buying, or obstruction of justice-that is, the unost common organized criminal activities. It was not clear what, if anything, should be done about the statute's overbreadth.

One of the first objections to RICO's scope came from the American Civil Liberties Umion (ACLU). In hearings on Senate Bill 1861 (a forerunner of the final RICO bill which defined racketeering activity as "any act involving the danger of violence to life, limb or property, indictable under State or Federal law and punishable by imprisonment for inore than one year"), ${ }^{69}$ the ACLU objected that "offenses of the kind [that] resulted froin the demonstrations in connection with the anti-war protest movement could fall within the definition of pattern of racketeering activity of the bill." ${ }^{\text {70 }}$ Further objections to RICO's scope came from the Department of Justice, which contended that the definition was "too broad and would result in a large nnmber of unintended applications." ${ }^{71}$ The Department of Justice also suggested its own model, which ennmerated the generic classes of crimes covered. ${ }^{72}$

In response to these objections, the Senate Subcommittee changed the definition to conforn with the Department of Justice model. Congress ultimately enacted this form of the statute. ${ }^{73}$ While this change seems to have been an attempt to narrow RICO's scope, it apparently was not a response to the ACLU's objections. ${ }^{74}$ Indeed, the ACLU reiterated its concern about the breadth of the statutory language during the subsequent House Hearings. ${ }^{75}$ However, this time the ACLU did not mention the

68. 116 CONG. REC. 18,940 (1970). (1969).

69. S. 1861, 91st Cong., 1st Sess. § 2(a) (1969); see also 115 Cong. REc. 9569

70. Senate Hearings, supra note 66, at 475 (testimony of Lawrence Speiser, Director, Washington Office, ACLU).

71. S. REP. No. 617, 91st Cong., 1st Sess. 121-22 (1969).

72. See id. at 121-22, 158.

73. See 18 U.S.C. § 1961(1)(A) (1994).

74. See 116 CoNG. REC. 852-56 (1970) (text of letter written by ACLU to Senate).

75. Organized Crime Control: Hearings on S. 30 and Related Proposals Before the Subcomm. No. 5 of the House Comm. on the Judiciary, 91st Cong., 2d Sess. 505 (1970) [hereinafter House Hearings] (testimony of Lawrence Speiser, Director, Washington Office, ACLU) (criticizing the statute's enabling of grand juries to offer reports without indictments as an unconstitutional compromise between the grand jury's power to indict and the protection of a state official). 
potential application to antiwar protesters, but instead focused on the possible application of RICO to simple drug purcliase or possession. ${ }^{76}$

The meaning of the congressional response is unclear. Much evidence, lowever, suggests that the legislature did not believe RICO would apply outside the bounds of organized crime. The Senate Committee Report is one of the best indicators of what Congress thought RICO meant when it passed the OCCA. For example, in its Statement of Findings and Purpose, the report focused exclusively on organized crime and the effect that it has on legitimate businesses, industries, and the economy of the entire nation. ${ }^{7}$ The exclusive focus was on the source of organized crime's power-money. Further, RICO had been designed to stop organized crime's infiltration of legitimate organizations. ${ }^{78}$ RICO was intended to meet the need for "new approaches that will deal not only with individuals, but also with the economic base through which those individuals constitute [a threat to] the Nation. In short, an attack must be made on their source of economic power itself, and the attack must take place on all available fronts."79 Thus, RICO was essentially an attack intended to cut the legs out from under organized crime and other racketeers.

Finally, there is significant evidence from the congressional debates that at least soine legislators behieved that RICO was clearly intended only for use against organized criminals. ${ }^{80}$ At one point, Senator McClellan argued that "[u]nless an individual not ouly commits such a[n enumerated] crime but engages in a pattern

76. House Hearings, supra note 75 , at 499 . On this point, the ACLU was joined by the Association of the Bar of the City of New York (ABCNY). Id.

77. S. REP. No. 617, 91st Cong., 1st Sess. (1969). The Report reads:

The Congress finds that (1) organized crime in the United States is a highly sophisticated, diversified, and widespread activity that annually drains billions of dollars from America's economy by unlawful conduct and the illegal use of force, fraud, and corruption; (2) organized crime derives a major portion of its power through money obtained fron such illegal endeavors [sic] as syndicated gambling, loan sharking, the theft and fencing of property, the importation and distribution of narcotics and other dangerous drugs, and other forms of social exploitation; (3) this money and power are mcreasingly used to infiltrate and corrupt legitimate business and labor unions ....

Id.

78. Id. at 76-77.

79. Id. at 79 .

80. 116 CONG. REC. 846 (1970) (arguing that Dr. Benjamin Spock's antiwar protests would not be covered by RICO because his actions "would not normally be considered organized crime"). 
of such violations, and uses that pattern to obtain or operate an interest in an interstate business, he is not made subject to proceedings under Title IX [RICO]." ${ }^{81}$ Another RICO supporter, Representative Poff, told his colleagues that RICO "does not violate the civil hberties of those who are not engaged in organized crime, but who nonetheless are within the incidental reach of provisions primarily intended to affect organized crime." ${ }^{182}$

There are a number of possible explanations for this apparent lack of concern on the part of RICO's supporters for the threat posed by the statute's broad language. One explanation, which RICO advocates espouse today, is that Congress deliberately constructed the statute to be a broad and powerful weapon that could be applied far beyond its central purpose. ${ }^{83} \mathrm{~A}$ better explanation, however, and one more in line witl the totality of the legislative history, is that Congress believed RICO's overbreadtl to be merely incidental; the pattern and enterprise requirements, inoreover, lielped clieck its potential for over-application. ${ }^{84}$ The courts, lowever, liave interpreted these features to their maximum breadtli. As a result, the overbreadth feared by the ACLU and otlier early RICO opponents lias been realized.

\section{B. Pattern Requirement}

Eacl subsection of RICO's section 1962 requires a "pattern of racketeering activity." "[A] 'pattern of racketeering activity' requires at least two acts of racketeering activity, one of whicl occurred after the effective date of this chapter and the last of which occurred within ten years (excluding any period of imprisonment) after the commission of a prior act of racketeering activity." From the outset, lowever, courts believed that the use of the phrase "requires at least" instead of the word "means" implied that more would be required. ${ }^{87}$ Indeed, the legislative history clearly supports this view. The Senate Report explained that "the

81. 116 CONG. REC. 18,940 (1970).

82. 116 CONG. REC. 35,344 (1970).

83. See Michael Goldsmith and Penrod W. Keith, Civil RICO Abuses: The Allegations in Context, 1986 B.Y.U. L. REv. 55, 73-75 (1986).

84. See infra Sections II(B)-(C) (discussing these constraints); see also Antonio J. Califa, RICO Threatens Civil Liberties, 43 VAND. L. REv. 805, 816 n.64 (1990).

85. 18 U.S.C. \& 1962(a)-(c) (1994).

86. 18 U.S.C. \& 1961(S) (1994).

87. See, e.g., Sedima, S.P.R.L. v. Imrex Co., Inc., 473 U.S. 479, 496 n.34 (1985). 
target of [RICO] is thus not sporadic activity. The infiltration of legitimate business normally requires more than one 'racketeering activity' and the threat of continuing activity to be effective. It is this factor of continuity plus relationship which combines to produce a pattern." 88

It was this phrasing which the Supreme Court seized upon when it addressed what else section 1961(5) required. In H.J., Inc. v. Northwestern Bell Tel. Co., phone company customers sued Northwestern Bell, alleging that it had bribed state regulators. ${ }^{89}$ The trial court dismissed the suit, finding that each act was part of a single scheme and did not constitute multiple schemes as it beheved RICO required; ${ }^{90}$ the Eighth Circuit affirmed..$^{91}$ The Supreme Court did not adopt the inultiple schemes approach and imstead found that two or more predicate acts constituted a pattern when they met the tests of "relatedness" and "continuity." Writing for the Court, Justice Brennan explained that these were two distinct tests, and though their proof might overlap, they both must establish a pattern. ${ }^{93}$

To define relatedness, the Court looked at Title $\mathrm{X}$ of the OCCA. ${ }^{94}$ That provision defined a pattern of racketeering activity as "einbrac[mg] criminal acts that have the same or similar purposes, results, participants, victims, or methods of commission, or otherwise are interrelated by distinguishing characteristics and are not isolated events." ${ }^{95}$ The Court believed that the Congress, in passing both statutes, had essentially the same thing in mind when it spoke of a pattern. ${ }^{96}$

No related statutes, however, provided the Court with any insiglit into Congress's conception of continuity. The Court explained continuity as essentially a "temporal concept" that coines in two varieties: closed and open-ended. ${ }^{97}$ Closed continuity means that one must prove "a series of related predicates extend-

88. S. REP. No. 617, 91st Cong., 1st Sess. 158 (1969).

89. 648 F. Supp. 419, 420 (D. Minn. 1986), affd, 829 F.2d 648 (8th Cir. 1987), rev'd, 492 U.S. 229 (1989).

90. Id. at 425 .

91. 829 F.2d 648, 650 (8th Cir. 1987), rev'd, 492 U.S. 229 (1989).

92. 492 U.S. $229,239-40$ (1989).

93. Id. at 240 .

94. Id. at 239-40.

95. 18 U.S.C. § 3575(e) (1988).

96. H.J., Inc., 492 U.S at 240.

97. Id. at $241-42$. 
ing over a substantial period of time." 98 Open-ended continuity was somewhat inore limited, requiring that the predicates establish a threat of long-term (i.e., more than weeks or even months) racketeering activities because they are part of an ongoing business or are the regular inethod of conducting the enterprise. ${ }^{99}$

The final result of the decision in H.J., Inc. was to leave the pattern requirement as broad as possible while still providing guidance to juries and trial courts. ${ }^{100}$ It has greatly broadened the scope of RICO in courts of appeals, such as the Eighth Circuit, that had previously adopted additional pattern elements.

\section{Enterprise Requirement}

The meaning of enterprise has followed a similar path in the courts. While explicitly defined im section 1961(4) as "includ[ing] any individual, partnership, corporation, association, or other legal entity, and any union or group of individuals associated in fact although not a legal entity," ${ }^{101}$ courts liave developed numerous interpretations of its precise meaning. ${ }^{102}$

In United States v. Turkette, ${ }^{103}$ the Supreme Court settled the debate over whether RICO mcluded both legitimate and illegitiinate enterprises. The Court noted that the First Circuit had relied on ejusdem generis, the rule of construction saying that when general terms are followed by a specific enumeration of examples the general term sliould be interpreted so that it is limited to things similar to those enumerated. ${ }^{104}$ The Court rejected this reasoning, finding that the appellate court had attempted to use the specific enumeration of legitimate business to limit the more general language describing a second category of enterprises that mcluded il-

98. Id. at 242.

99. Id. at $241-43$.

100. Justice Scalia, however, believed that the H.J., Inc. decision provided hittle direction at all. In his concurring opinion, Justice Scalia opined that in hight of the then-existing disparity in lower court opinions on the meaning of pattern, the Court's definition of "continuity plus relationship" would be about as nseful as the phrase "life is a fountain." Id. at 252 (Scalia, J., concurring).

101. 18 U.S.C. \& 1961(4) (1994).

102. See, e.g., United States v. Pelullo, 964 F.2d 193 (3d Cir. 1992); United States v. Perholtz, 842 F.2d 343 (D.C. Cir.), cert. denied, 488 U.S. 821 (1988); Schaffer v. Williams, 794 F.2d 1030 (5th Cir. 1986); United States v. Mazzei, 700 F.2d 85 (2d Cir.), cert. denied, 461 U.S. 945 (1983).

103. 452 U.S. 576 (1981).

104. Id. at 581 . 
legitimate enterprises; ${ }^{105}$ that is, "enterprise includes any union or group of individuals associated in fact. On its face, the definition appears to include both legitimate and illegitimate enterprises within its scope."106

In the years after Turkette, the lower courts continued to develop rules for determining the elements of a RICO enterprise. The Third and Eighth Circuits have been particularly active in outlining the characteristics of a RICO enterprise. ${ }^{107}$ These circuits have identified three traits that all RICO enterprises share. First, an enterprise has a common purpose toward which the members all work. ${ }^{108}$ Second, an enterprise has an ongoing organization and structure. It includes a structure within the group for making decisions that may be hierarchical or consensual but will be more than merely ad hoc. ${ }^{109}$ The structure also includes a continuous organization of the inembers such that each person has a role that furthers the purpose of the enterprise. ${ }^{110}$ While the ongoing nature of the structure requires a continuity of personnel, it does not mean that the continuity must be absolute. ${ }^{11}$ An enterprise does not dissolve with the loss or replacement of a single meinber; nor is it absolutely true that two predicates committed by different sets of individuals cannot be part of a single enterprise. $^{112}$ The key is whether there is a continual, discernible structure to the organization. ${ }^{113}$

The third characteristic of an enterprise is that it has an "existence beyond that which is necessary inerely to commit each of the acts charged as predicate racketeering offenses."114 In other

105. Id. at $581-82$.

106. Id. at 580 .

107. See, e.g., United States v. Console, 13 F.3d 641 (3d Cir. 1993), cert. denied, 114 S. Ct. 1660 (1994); United States v. Leisure, 844 F.2d 1347 (8th Cir.), cert. denied, 488 U.S. 932 (1988); United States v. Riccobene, 709 F.2d 214 (3d Cir. 1983), cert. denied, 464 U.S. 849 (1983); United States v. Bledsoe, 674 F.2d 647 (8th Cir.), cert. denied, 459 U.S. 1040 (1982); United States v. Lemm, 680 F.2d 1193 (8th Cir. 1982), cert. denied, 459 U.S. 110 (1983). But cf. United States v. Pelullo, 964 F.2d 193 (3d Cir. 1993); United States v. Perholtz, 842 F.2d 343 (D.C. Cir.), cert. denied, 488 U.S. 821 (1988); Schaffer v. Williams, 794 F.2d 1030 (5th Cir. 1986); United States v. Mazzei, 700 F.2d 85 (2d Cir.), cert. denied, 461 U.S. 945 (1983).

108. Lemm, 680 F.2d at 1199.

109. Riccobene, 709 F.2d at 222.

110. Console, 13 F.3d at 651.

111. Lemm, 680 F.2d at 1199.

112. See id. at $1199-1200$.

113. See id. at 1199.

114. United States v. Riccobene, 709 F.2d 214, 224 (3d Cir. 1983), cert. denied, 464 
words, a RICO enterprise is something more than a mere conspiracy to commit a predicate offense. This element, however, may be satisfied by the organization's existence as an ongoing planning body that oversees and directs the commission of predicate offenses. ${ }^{115}$

In addition, some circuits found another characteristic of RI$\mathrm{CO}$ enterprises that was particularly significant in cases involving social protesters. This element was an economic or profit motive. For example, in United States v. Flynn, the Eighth Circuit held that "[f]or purposes of RICO, an enterprise must be directed toward an economic goal."116 The economic motive requirement rehes on the different roles of enterprise in section 1964(a) and (b) and its role in section 1964(c). ${ }^{117}$ These courts found that the enterprises under subsections (a) and (b) are clearly economic entities. Therefore, they inferred that subsection (c) must also require an economic organization. ${ }^{118}$ However, the Supreme Court recently overturned those decisions in National Organization for Women v. Scheidler. ${ }^{119}$ The Court found that the express language of the statute clearly suggested different uses of enterprise among the subsections, and that nothing in the legislative history conclusively pointed otherwise. ${ }^{120}$

Thus, as with the pattern requirement, the judiciary has interpreted the enterprise language of RICO in its absolute broadest manner. Indeed, the most restrictive element of the enterprise requirement is the separation of enterprise from pattern. This serves to differentiate RICO from ordinary conspiracy, but in this form it does nothing to minimize the statute's recognized overbreadth as the drafters seem to have beheved it would.

U.S. 849 (1983); see also United States v. Turkette, 452 U.S. 576, 583 (1981); United States v. Lemm, 680 F.2d 1193, 1200-01 (8th Cir. 1982), cert. denied, 459 U.S. 110 (1988).

115. See Riccobene, 709 F.2d at 224 .

116. 852 F.2d 1045, 1052 (8th Cir.), cert. denied, 488 U.S. 974 (1988); see also National Org. for Women v. Scheidler, 968 F.2d 612, 626-29 (7th Cir. 1992), rev'd, 114 S. Ct. 798 (1994); United States v. Ivic, 700 F.2d 51, 60-61 (2d Cir. 1983).

117. See 18 U.S.C. $\$ 1964$ (1994); cases cited supra note 36.

118. Ivic, 700 F.2d at 60-61; Scheidler, 968 F.2d at 626-29.

119. 114 S. Ct. 798, 806 (1994).

120. Id. at 804-05. 


\section{APPLICATION to POLITICAL PROTESTERS}

Although there have been recent applications of RICO to other political protesters, ${ }^{121}$ the most prevalent application of civil RICO to protesters is in the national debate over abortion. Given this fact and that the abortion cases present some of the most extreme examples of RICO's application, this Note focuses on these cases. It also draws parallels to other areas of political protest.

\section{A. Hobbs Act and Predicate Offenses}

1. Interstate Commerce. Given the breadth of the interstate commerce requireinent, it seems unlikely that this requirement would ever pose a difficulty to plaintiffs, even though the connection is extremely tenuous in many cases involving protesters. Indeed, a survey of the reported cases reveals that no protester defendants have argued successfully that their activities did not affect interstate commerce. Two brief examples illustrate this point. In Town of West Hartford $v$. Operation Rescue, ${ }^{122}$ the defendants argued that the plaintiffs failed to show that defendants had adversely affected interstate commerce. In its decision, however, the trial court completely ignored this argument, relying imstead on the defendants' lack of an economic motive. ${ }^{123}$ Similarly, the Third Circuit showed an equal lack of concern for the imterstate commerce issue when it decided Northeast Women's Center, Inc. v. McMonagle. ${ }^{124}$ In that decision, the court disposed of both the Hobbs Act and the RICO interstate commerce questions in a single short footnote: "[T]here was ample evidence that the Center [plaintiff], a profit-making institution, advertised in interstate commerce and drew patients from other states, thereby satisfying

121. See, e.g., Avirgan v. Hull, 691 F. Supp. 1357, 1359-60 (S.D. Fla. 1988) (involving a bombing that targeted a Nicaraguan opposition leader), aff d, 932 F.2d 1572 (11th Cir. 1991), cert. denied, 502 U.S. 1048 (1992); Walden Book Co. v. American Family Ass'n of Fla., Inc., No. 89-2426 (S.D. Fla. filed Oct. 31, 1989) (charging the defeudants with extortiou for threatening to publicly label Playboy magazine as obscene); Penthouse Int'l v. American Family Ass'n of Fla., Inc., No. 89-2526 (S.D. Fla. filed Nov. 14, 1989) (addressing the same issues as to Penthouse).

122. 792 F. Supp. 161 (D. Conn. 1992), vacated in part, 991 F.2d 1039 (2d Cir.), cert. denied, 114. S. Ct. 185 (1993).

123. Id. at 168.

124. 868 F.2d 1342 (3d Cir.), cert. denied, 493 U.S. 901 (1989). 
the RICO interstate commerce requirement."125 In light of cases like these, the interstate commerce requirement appears to be hittle more than a pleading formality.

2. Property. Plaintiffs generally have rehed on the broadest interpretations of property to successfully bring RICO claims against defendant protesters. Once again, the McMonagle decision serves as a case in point. In that decision, the Third Circuit looked to decisions such as United States v. Local 560, ${ }^{126}$ United States $v$. Santoni ${ }^{127}$ and United States v. Zemek ${ }^{128}$ for the proposition that "[r]ights involving the conduct of business are property rights" within the ineaning of the Hobbs Act. ${ }^{129}$ In McMonagle, the rights in question were the right to contmue to provide abortion services; the right of employees to continue their einployment with the clinic; and the patients' right to contract with the Center. ${ }^{130}$ And while defendants in these cases have protested that they sought no property, ${ }^{131}$ the courts seem to favor the plaintiffs in these cases. ${ }^{132}$

Some would suggest that Town of West Hartford v. Operation Rescue halted the expansion of the property element. ${ }^{133}$ In that case, the town claimed that protesters had extorted "from the Town its ability to protect the rights of the Center, its patients, and the Town's citizens."134 The town's claims were dismissed on appeal for lack of subject matter jurisdiction on the ground that the protesters had obtained no property from the town. ${ }^{135}$ Finding that almost any action by the defendants might result in activity by the government, the Second Circuit reasoned that "[i]t

125. Id. at 1349 n.6.

126. 780 F.2d 267, (3rd Cir. 1985), cert. denied, 476 U.S. 1140 (1986).

127. 585 F.2d 667 (4th Cir. 1978), cert. denied, 440 U.S. 910 (1979).

128. 634 F.2d 1159 (9th Cir. 1980), cert. denied, 450 U.S. 916 (1981).

129. McMonagle, 868 F.2d at 1350.

130. Id.

131. See Brief for Respondents Joseph M. Scheidler, Andrew Scholberg, and the ProLife Action League, Inc. at 6, National Org. for Women v. Scheidler, 114 S. Ct. 798 (1994) (No. 92-780).

132. See supra Section I(C).

133. Town of West Hartford v. Operation Rescue, 726 F. Supp. 371 (D. Conn. 1989), vacated, 915 F.2d 92 (2d Cir. 1990).

134. Id. at 376.

135. Town of West Hartford v. Operation Rescue, 915 F.2d 92, 99-104 (2d Cir. 1990). 
is simply not tenable to translate the activation of such a response into a Hobbs Act obtention of property." 136

This decision in favor of the protesters, however, cannot be viewed as the end of RICO's expansion. First, the Second Circuit has been one of the few courts to oppose RICO expansion; the result may have been different in many other circuits. ${ }^{137}$ Second, even the judges within the panel for Town of West Hartford could not agree. In her dissent, Judge Kease argued that the town's assertion that it had been forced to pay extra money to its einployees was not substantially different from an assertion that it had been forced to hire extra employees; the latter characterization would have been considered property within the Hobbs Act. ${ }^{138}$ These facts resenble those in McMonagle, in which damages were based on the clinic's increased security costs. ${ }^{139}$ Viewed from this perspective, it is difficult to see why the inunicipality was not entitled to recover its increased costs. ${ }^{140}$ In a more RICO-friendly court, the decision probably would have been different.

3. Fear. In the protest context, the fear element is the inost difficult to apply. Simple picketing, for example, can hardly be said to be threatening in any physical sense. It could be viewed, however, as a threat to the ability of a business to attract

136. Id. at 102 .

137. The Second Circuit has been a long-time advocate of limiting RICO. It apphied an economic notive requirement in United States v. Ivic, 700 F.2d 51, 59 (2d Cir. 1983), and required proof of criminal convictions and of a "racketeering injury" separate from the injury of the predicate act in Sedima, S.P.R.L. v. Imrex Co., 741 F.2d 482, 496, 503 (2d Cir. 1984), rev'd, 473 U.S. 479 (1985). Judge Mahoney may have summed it up best in West Hartford when he admonished that the court's willingness to enforce RICO as written by Congress "does not imply ... any disposition on the part of this court to countenance fanciful invocations of the draconian RICO weapon in civil litigation." 915 F.2d at 104. Other courts are more open to such innovative applications by plaintiffs. See, e.g., Northeast Women's Center, Inc. v. McMonagle, 868 F.2d 1342 (3d Cir.), cert. denied, 493 U.S. 901 (1989); National Org. for Woinen v. Scheidler, 114 S. Ct. 798 (1994).

138. West Hartford, 915 F.2d at 105; see supra Section I(C).

139. Northeast Women's Center, Inc. v. McMonagle, 689 F. Supp. 465, 476 (E.D. Pa. 1988), affd, 868 F.2d 1342 (3d Cir. 1989), cert. denied, 493 U.S. 901 (1989).

140. The West Hartford court based its reasoning in large measure on a conparison to Clayton Act decisions that only permitted a government to recover when injured in its commercial interests. West Hartford, 915 F.2d at 103-04. The decision to view the town's definite, hquidated overtime costs as nore closely related to imjuries to a state's general economy than as particular commercial transactions seens to reflect the court's bias against RICO rather than careful reasoning. 
customers and to continue operating. Yet, even in that context, the usual picketing lacks what one commentator has termed the "imperative quality" present in the inore typical extortion scheme. ${ }^{141}$ The difficulty for courts is ensuring that the protesters lave acted beyond their rights under the First Amendment. The general primciple imvolved is that while the First Amendment protects speech (including coercive and offensive speech), ${ }^{142}$ the right to free speech "does not offer a sanctuary for violators [of the law]." "143

The McMonagle case provides the paradigmatic fact pattern. There, the district court found four separate "trespasses" that precipitated the tortious and extortionate acts. ${ }^{144}$ On the first occasion, protesters entered the clinic, blocking access to some of the rooins and throwing medical supplies to the floor. ${ }^{145}$ One einployee testified that she was injured while trying to prevent the protesters' entry and that sle subsequently quit her job until the clinic installed a more sophisticated security system. ${ }^{146}$ The next two incidents occurred over a year later when about a dozen protesters entered the clinic again, this time locking theinselves in an operating rooin, and damaging and taking medical equipment. ${ }^{147}$ Six months later the fourth event followed: Demonstrators were videotaped "sitting down on the floor of a waiting room inside the clinic, standing in front of patients awaiting services and castigating them, and ignoring repeated requests that they cease trespassing and leave the building." 148 The circuit court further described testimony that it regarded as addressing the extortion and fear questions:

[A]n assistant district attorney who witnessed a demonstration testified that the demonstrators' activity rose to a "frenzy" and that he delayed leaving the Center out of fear for his physical safety. ... A protester is recorded stating, "I bet you ten to one this place doesn't last six months." Another added, "This place is going to be shut down." [Finally, t]hree employees testified that

141. Califa, supra note 84 , at 828 n.122.

142. NAACP v. Claiborne Hardware Co., 458 U.S. 886, 911 (1982).

143. McMonagle, 868 F.2d at 1349 (quoting district court's charge to jury).

144. Id. at 1345-46.

145. Id. at 1345 .

146. Id.

147. Id. at 1346.

148. Id. 
they were repeatedly subjected to picketing at their homes. Two of these employees stated that they resigned from their positions at the Center because of Defendants' actions at their homes and the Center. ${ }^{149}$

The circuit court went on to approve of the trial judge's jury instruction that the protesters had a constitutional right to persuade the clinic to stop performing abortions, the employees to stop working at the Center, and the patients not to have abortions-even if some of their protests were coercive or offensive. ${ }^{150}$ But, as the court reasoned, the same Constitution which protected the protesters' acts also protected the Center's right to perform abortions and the patients' rights to receive them; it did not offer sanctuary for violators. ${ }^{151}$ In hight of these precise instructions, the Third Circuit asserted with confidence that the jury award of damages "estabhishes that the jury found that Defendants' actions went beyond mere dissent and publication of their political views." 152

This decision poses the difficult question of identifying at what point the protesters crossed the line from protected protest to Hobbs Act and RICO violations. One commentator has suggested that the protesters crossed the line when they coinbined coercive speech and trespass. ${ }^{153}$ Trespass is clearly not protected by the Constitution, but it is difficult to see how this criminal act changes the speech from noncriminal to extortionate. While the physical location of the speaker may make the speech more intrusive and immediate, its essential character is not altered.

The "speech-plus-trespass" justification also might be explaimed if the coercive speech is extortionate wherever the speaker may be. Under this view, whether the protesters are on the public sidewalk or on the climic's property, they are attempting to extort a clinic's right to operate when they threaten to picket and confront patients and employees until it ceases performing abortions. However, as long as the protesters stay on the sidewalk, they are within the protection of the First Amendment, and no laws, including RICO and the Hobbs Act, can touch them. When the pro-

149. Id. at 1346 (citations omitted).

150. Id. at 1349.

151. Id.

152. Id.

153. See Califa, supra note 84 , at $828-29$ n.122. 
testers exceed their constitutional rights by committing a trespass, however, they immediately fall within the Hobbs Act.

This view is useful to the debate, but it does not go far enough. It leaves many forms of protest and civil disobedience, such as sit-ims, unprotected. While the tenets of civil disobedience call for submitting to the sanctions of an unjust law, it is contrary to principles of democratic government to impose RICO's severe penalties on such activists. Consider, for example, the fact that a protest that successfully persuades significant numbers of potential customers from patronizing a store could be liable for three times the profits the store might lave expected if only a few individuals trespass onto the store's property. Furtherinore, this argument seems to ignore an essential difference between protest and extortion, which should militate against bestowing sucl a windfall upon the plaintiff.

\section{B. $R I C O$}

Given RICO's vast expansion over the past two decades, plaintiffs generally have little difficulty bringing protesters within its statutory parameters. Yet, plaintiffs must generally rely on the broadest understandings of these requirements, particularly in meeting the pattern and enterprise requirements.

1. Pattern Requirement. The relatedness half of the pattern requirement ${ }^{154}$ poses little difficulty im the typical case involving protesters. Indeed, these cases generally involve the same purposes (stopping the target activity); participants (members of the protest organization); victims (those engaging in the offensive activity); and commission (from picketing to trespassing). In short, the plaintiffs usually have their choice of avenues for meeting this prong and typically can adjust their pleading to accommodate the available evidence.

Continuity ${ }^{155}$ is also a fairly easy element for plaintiffs to satisfy in the protest context. By their very nature, protest campaigns are long-tern affairs. Protesters must be present day in and day out if their efforts are to liave any perinanent effect. In McMonagle, for example, the trespasses occurred over a period of

154. See supra notes $94-96$ and accompanying text.

155. See supra notes $97-99$ and accompanying text. 
more than two years; in Scheidler, the plaintiffs catalogued the protest leaders' activities over as inuch as six years. ${ }^{156}$ When the protests continue for soine extended period, the plaintiffs clearly can claim to have established close-ended continuity; and when there is not yet a long history of offenses, as in West Hartford, there will often be enough evidence available to convince a court that the activities could continue. ${ }^{157}$

It might be inore difficult to establish a pattern if the Supreme Court had adopted the Eighth Circuit's "multiple schemes" test $^{158}$ or the more complicated multi-factor test of the Seventh Circuit. ${ }^{159}$ Under the current interpretation, however, nearly any organized protest inovement would fit the statutory definition.

2. Enterprise. The enterprise requirement has a mixed history in the context of RICO's application to protestors. In some cases, such as McMonagle, the satisfaction of the enterprise requirement was never an issue. ${ }^{160}$ Courts and parties alike seem to have tacitly accepted that the broad requirements of common purpose, ongoing organization, and separate existence are easily satisfied when the defendants are part of an organized novement. In other courts, lowever, the enterprise requireinent has been a shield protecting protesters from the "draconian RICO weapon"161 through the economic motive requirement. ${ }^{162}$

But even in the post-Scheidler world, the enterprise requirement seems to be the inost difficult requirement for RICO plaintiffs to meet. Protestors may be able to take steps in order to avoid RICO liability. Consider the District Court's mitial decision in West Hartford:

156. See McMonagle, 868 F.2d at 1345-46; National Org. for Women v. Scheidler, 968 F.2d 612, 615 (7th Cir. 1992), rev'd, 114 S. Ct. 798, 806 (1994) (cataloguing protest leaders' activities dating to 1986).

157. Town of West Hartford v. Operation Rescue, 726 F. Supp. 371, 373, 375 (D. Conn. 1989) (finding that two protests had already occurred and that "[t]he Center has been shown to be a likely target for repetition of the demonstrations."), vacated, 915 F.2d 92 (2d. Cir. 1990).

158. See H.J., Inc., v. Northwestern Bell Tel. Co., 492 U.S. 229, 234 (1989).

159. See Morgan v. Bank of Waukegan, 804 F.2d 970, 974-77 (7th Cir. 1986).

160. The satisfaction of the enterprise requirement is not discussed in any of the McMonagle decisions. See Northeast Women's Center, Inc. v. McMonagle, 665 F. Supp. 1147 (E.D. Pa. 1987); McMongle, 868 F.2d at 1342.

161. West Hartford, 915 F.2d at 104.

162. See supra Section II(C). 
[Common Purpose:] On each date, a large number of persons ... blocked the offices of the Center ... for the purpose of closing down the Center and preventing and discouraging abortions. ${ }^{163}$

[Ongoing Organization and Structure:] The demonstration and rescue was organized, prepared, and orchestrated.... On each day, from among the demonstrators, one or more persons presented themselves to officials as "negotiators" authorized to speak for the arrestees. The arrestees responded to instructions from negotiators. ... There appears to be a substantial association of people who are committed to eliminating the availability of abortions. The association appears to be loose and not formed. ${ }^{164}$

[Separate Existence: G]roups have associated under [various] names. . . Except for Pro-Life, Inc., none is shown to have a legal status. While Randall Terry has written the "bible" for rescuers and proclaims a role in "Operation Rescue," [evidence did not show lime to have had a ... role in either incident. ... Defendant Pollock. ... was shown to have exercised a leadership and organizational role in each demonstration. ${ }^{165}$

These passages illustrate some of the difficulties that can arise in establishing a RICO enterprise. For example, while a common purpose can easily be established in any organized protest, it is more difficult to show that the protesters are acting under any organized structure. In Town of West Hartford, some individuals claimed to speak for the group, but the court did not seem convinced that the decisionmaking structure was anything more than ad hoc. ${ }^{166}$ Similarly, the court's findings make it clear that the protesters' tactic of refusmg to carry or provide identification made it very difficult for either officials or plaintiffs to establish any consistent membership at the protests. ${ }^{167}$

A similar difficulty arises in determining whether the enterprise here had any existence separate from that necessary to carry out the predicate acts. On the one hand, numerous organizations

163. West Hartford, 726 F. Supp. at 373.

164. Id. at 374-75.

165. Id. at 375 .

166. Id. at 374-75.

167. Id. 
were claimed to have been represented at the protest, and yet only one seems to have had any legal status. ${ }^{168}$ Similarly, while Randall Terry was a named defendant, the plaintiffs were unable to estabhsh his involvement. ${ }^{169}$ Finally, although the court did identify one individual as having had a "leadership" role in all the protests, ${ }^{170}$ it did not discuss whether that person was any more than a mere co-conspirator.

It may be encouraging for those who oppose the broad apphcability of RICO that protestors can avoid hability. From a broader view, however, it should be disturbing that RICO would produce this effect. It is the ad hoc, amorphous nature of such protests that may suffice to prevent an enterprise finding. And yet it is precisely this kind of disorganization and lack of centralized authority which can turn a peaceful picket into a near riot. By encouraging protesters to avoid organization, RICO perversely may encourage exactly the kind of chaos that plaimtiffs are employing it to attack. If RICO were read in a more limited fashion, this type of chaos could be avoided.

\section{CONCLUSION}

Serious constitutional implications exist when extraordinary damages are made available in the context of pohtical activism. A long line of cases has protected picketing and political protest throughout American history. ${ }^{171}$ A tool of RICO's breadth and power should be of concern to all who may find themselves engaged in protest someday. While today the targets are anti-abortion protesters who have developed a reputation for fanaticism as well as the use of violence on a few notable occasions, ${ }^{172}$ tomorrow RICO may be apphed to other political movements engaged

168. Id. at 376 .

169. Id. at 375 .

170. Id.

171. See, e.g., Edwards v. South Carolina, 372 U.S. 229 (1963); NAACP v. Alabama ex rel. Patterson, 357 U.S. 449 (1958); Thornhill v. Alabama, 310 U.S. 88 (1940). For a more detailed discussion of the First Amendment and civil rights concerns posed by expanding RICO, see Califa, supra note 84.

172. Susan Faludi, The Antiabortion Crusade of Randall Terry, WASH. PosT, Dec. 23, 1989, at C2; Janice Mall, About Women: Harassment of Abortion Clinics Growing, L.A. TIMES, Apr. 26, 1987, Part 6, at 8; Laurie Goodstein, Anti-Abortion Violence Escalating at Clinics, ChICAgo Sun-Times, Jan. 20, 1995, at 8. 
in "direct action" tactics, such as environmental, animal rights, and gay rights activists.

This Note has demonstrated the extreme degree to which RICO and its predicates must be stretched to reach political protesters. Originally designed as a statute to pumish protection scams and criminal shakedowns, the Hobbs Act has been transformed into a way to punish picketing. RICO has expanded beyond career criminals who insidiously buy up legitimate companies to launder their ill-gotten gains to pohtical activists who proclaim their message in the public square. To suggest that the same statutes should be used to control activities on both ends of the spectruin is absurd. The legal community should consider conducting a simple survey of the general pubhic that consists of two separate questions: "Is picketing the same as extortion?" and "Are protesters racketeers?" Stripped of the intricate legal deconstruction discussed in this Note, the extent of the double-stretch of RICO becomes clear. RICO has not yet faced a full-force confrontation with the First Amendinent, but one is clearly coming unless Congress acts soon. ${ }^{173}$ It is time to draw a line in the sand before the sand runs out.

173. Congressional reform of RICO has often been proposed, at least three times in the past two Congresses, but has never succeeded. See H.R. 3522, 101st Cong., 1st Sess. (1989); Bill to Limit RICO Fails to Reach Floor, 47 CoNG. Q. AlMANAC 292, 292-93 (1991); Attempts to Limit RICO Fail Again, 46 Cong. Q. AlmanaC 536, 536-38 (1990). 